\title{
PERSUASIVE STRATEGIES USED BY INSURANCE AGENTS IN PROSPECTING CUSTOMERS BASED ON THE CUSTOMERS' AGE FACTOR
}

\author{
Olivia Olga Wijaya, Herwindy Maria Tedjaatmadja \\ English Department, Faculty of Letters, Petra Christian UniversitySurabaya, East Java, Indonesia \\ e-mail: oliviaolga.w@gmail.com,windy382@petra.ac.id
}

\begin{abstract}
This study aimed to find out the persuasive strategies used by $\mathrm{X}$ insurance agents in prospecting the customers and reveal the differences and similarities between persuasive strategies used by insurance agents in prospecting same-age customers and older customers. Through this study, the writer tried to relate the persuasive strategies used by insurance agents to the customers' age factor. The writer chose three insurance agents who worked in X Insurance company and classified the customers into two categories based on their ages; firstly, customers who are in the same-age group as the agents; secondly, customers who are in differentage (older) group from the agents. In the findings, it turned out that in prospecting both customers' categories, the insurance agents used both persuasive strategies proposed by Beebe \& Beebe (2012); however some methods of persuasion strategies were not used at all. This study concluded that the age of the customers does not really affect the way insurance agents prospect their customers.
\end{abstract}

Key words: Persuasive Strategies, Persuasion, Age

\section{INTRODUCTION}

Persuasion is very important in business world because every type of businesses needs persuasion to influence people so that they want to buy and use the product it offers. According to Beebe $\&$ Beebe (2012, p.314), persuasion is the process of changing or reinforcing attitudes, beliefs, values, or behavior. In doing a persuasion, people need some persuasive strategies that will help them in convincing other people. Persuasion strategies according to Larson $(2004$, p.20) is the overall step by step program for reaching some goals.

One type of businesses which depends on persuasion a lot is insurance company. Insurance is an arrangement with a company in which you pay them money, especially regularly, and they pay the costs if something bad happens, for example if you become ill or your car is damaged (Longman Dictionary, 2001. p.739). In order to persuade customers to join insurance, an insurance agent will try to convince and persuade the customers so that they want to believe in or agree to what he or she says. Therefore, in doing a persuasion, insurance agents need persuasive strategies that will help them in persuading the other side. Persuasion strategies according to Larson (2004, p.20) is the overall step by step program for reaching some goals.

Actually, the persuasive strategies used by salespeople to persuade other parties could be affected by some factors such as the cultural background, gender, and age. According to Yoon et al (2005, p.6), older consumers tend to be more easily persuaded by messages that are more goalrelevant. Based on that theory, the writer expects that age of the customers may affect the way insurance agents use the persuasive strategies. The writer has two objectives; firstly, the writer wants to find out the persuasive strategies used by $\mathrm{X}$ insurance agents in prospecting the customers. Secondly, the writer aims to reveal the differences and similarities between persuasive strategies used by $\mathrm{X}$ insurance agents in prospecting customers who are in the same-age group and customers who are in different-age (older) group.

In analyzing the data, the writer uses some theories and related studies. Firstly, the writer uses theory of persuasive strategies by Beebe \& Beebe (2012, p.340 - 354). Beebe \& Beebe (2012) proposed two persuasive strategies, which are using logic and evidence to persuade and using emotion to persuade. There are three ways of using logic and evidence to persuade, which are inductive reasoning, deductive reasoning, and causal reasoning. Meanwhile, there are eight structures of using emotion to persuade; use concrete examples that help your listeners visualize 
what you describe, use nonverbal behavior to communicate, use emotion-arousing words, use visual images to evoke emotions, use appropriate metaphors and similes, use appropriate fear appeals, consider using appeals to several emotions, and tap audience members' beliefs in shared myths. As another main theory, the writer also uses persuasive strategies and age by Yoon et al (2005). Some research (Carstensem et al., 1999, Blaney, 1986, Clary et al, 1994, cited in Yoon et al, p.6-7) implies that emotionally-relevant messages are much more attractive for older adults.

The writer also uses some studies which have been done before to get information related to the study. The thesis entitled Persuasive Strategies Used on the Phone by Male and Female Insurance Salespeople in Surabaya (Hatane, 2011) helps the writer to have a better understanding of how to deal with insurance agents. Moreover, the writer uses Characteristics of the Persuasive Strategies table of Persuasive Strategies Used by James Farmer Jr. and Samantha Booke in the Great Debaters Film (Alexander, 2012).

\section{METHODS}

This study used descriptive qualitative approach to get and analyze the data. In order to get the data, the writer would analyze the verbal communication between insurance agents and their customers. The writer chose three insurance agents who are in their 20 s because the people who are in their 20s are considered to be young people. Also, the writer chose insurance agents who have worked in $\mathrm{X}$ insurance company at least for one year. The writer chooses to get the data from $\mathrm{X}$ insurance company because X insurance company is selected by Investor Magazine in 2015 as one of the best insurances in Indonesia.

Since this study concerned about the customers' age factor, the writer classified the customers into two categories based on their age; firstly, customers who are in the same-age group as the agents and secondly, customers who are in different-age (older) group from the agents. Each insurance agent would prospect two customers; one from same-age group, and the other one from older group. The writer recorded the real conversations that happened while the insurance agents were prospecting their customers.

The unit of analysis in this study was per utterance. Utterance means speech that was bounded by silence. One utterance could be analyzed as more than one persuasive strategy. The writer classified the persuasive utterances based on the customers' age. Furthermore, the writer also separated the data based on Beebe \& Beebe's persuasive strategy theory (2012) and categorized the data into the methods of persuasive strategies. After that, the writer found the persuasive strategy that was mostly used by insurance agents in prospecting different-age (older) customers and sameage customers by calculating the percentage of each method and strategy.

\section{FINDINGS AND DISCUSSION}

Firstly, the writer would answer the first research question; The persuasive strategies used by insurance agents in prospecting customers who are in the same-age group and customers who are in different-age (older) group.

Table 1: Persuasive Strategies Used by Insurance Agents in Prospecting Customers who are in The Same-age Group

\begin{tabular}{|l|l|c|c|}
\hline \multicolumn{2}{|c|}{ Persuasive Strategies } & \multicolumn{2}{c|}{ Same-age Group Customers } \\
\cline { 3 - 4 } & Number & Percentage \\
\hline \multirow{2}{*}{\begin{tabular}{l} 
Using Logic and $\begin{array}{l}\text { Evidence to } \\
\text { Persuade }\end{array}$ \\
\cline { 2 - 4 }
\end{tabular}} & Inductive Reasoning & 31 & $\mathbf{3 3 . 3 3 \%}$ \\
\cline { 2 - 4 } & Deductive Reasoning & 25 & $\mathbf{2 6 . 8 8 \%}$ \\
\cline { 2 - 4 } & Causal Reasoning & 0 & $\mathbf{0 \%}$ \\
\cline { 2 - 4 } $\begin{array}{l}\text { Total } \\
\text { Persuade Emotion to }\end{array}$ & $\begin{array}{l}\text { Use concrete examples that } \\
\text { help your listeners visualize } \\
\text { what you describe }\end{array}$ & 21 & $\mathbf{2 2 . 5 8 \%}$ \\
\cline { 2 - 4 } & $\begin{array}{l}\text { Use emotion-arousing } \\
\text { words }\end{array}$ & 0 & $\mathbf{0 \%}$ \\
\hline
\end{tabular}




\begin{tabular}{|l|l|c|c|}
\hline & $\begin{array}{l}\text { Use visual images to evoke } \\
\text { emotions }\end{array}$ & 1 & $\mathbf{1 . 0 7 \%}$ \\
\hline $\begin{array}{l}\text { Use appropriate metaphors } \\
\text { and similes }\end{array}$ & 3 & $\mathbf{3 . 2 2 \%}$ \\
\hline Use appropriate fear appeals & 0 & $0 \%$ \\
\hline $\begin{array}{l}\text { Consider using appeals to } \\
\text { several emotions }\end{array}$ & 11 & $\mathbf{1 1 . 8 3 \%}$ \\
\hline $\begin{array}{l}\text { Tap audience members' } \\
\text { beliefs in shared myths }\end{array}$ & 1 & $\mathbf{1 . 0 7 \%}$ \\
\hline Total & $\mathbf{3 7}$ & $\mathbf{3 9 . 7 8 \%}$ \\
\hline TOTAL & $\mathbf{9 3}$ & $\mathbf{1 0 0 \%}$ \\
\hline
\end{tabular}

From the table, the writer concluded that in prospecting the customers who are in the sameage group, the insurance agents used both persuasive strategies, but some methods such as causal reasoning, emotion-arousing words, and appropriate fear appeals were not used. There was a possibility that the insurance agents did not use some methods because they were not really close and familiar with the customers. The customers might find it was impolite if the insurance agents used emotion-arousing words and appropriate fear appeals in their first meeting. Furthermore, the insurance agents used more logic and evidence in persuading the same-age customer, especially by using inductive reasoning (33.33\%). Probably, the insurance agents preferred to use inductive reasoning when the insurance agents wanted to persuade or reassure the customer about something because most of the time, inductive reasoning was used when the agents tried to convince the customer to believe in what they said and join the insurance.

Table 2: Persuasive Strategies Used by Insurance Agents in Prospecting Customers who are in The Different-age (Older) Group.

\begin{tabular}{|l|l|c|c|}
\hline \multicolumn{2}{|c|}{ Persuasive Strategies } & \multicolumn{2}{c|}{$\begin{array}{c}\text { Different-age (Older) } \\
\text { Customers }\end{array}$} \\
\cline { 2 - 4 } \multicolumn{2}{|l|}{$\begin{array}{l}\text { Using Logic and } \\
\text { Evidence to } \\
\text { Persuade }\end{array}$} & Number & Percentage \\
\cline { 2 - 4 } & Deductive Reasoning & 28 & $\mathbf{2 8 . 2 8 \%}$ \\
\cline { 2 - 4 } & Causal Reasoning & 0 & $\mathbf{4 5 . 4 5 \%}$ \\
\cline { 2 - 4 } & Total & $\mathbf{7 3}$ & $\mathbf{7 3 . 7 3 \%}$ \\
\hline $\begin{array}{l}\text { Using Emotion to } \\
\text { Persuade }\end{array}$ & $\begin{array}{l}\text { Use concrete examples that } \\
\text { help your listeners visualize } \\
\text { what you describe }\end{array}$ & 14 & $\mathbf{1 4 . 1 4 \%}$ \\
\cline { 2 - 4 } & $\begin{array}{l}\text { Use emotion-arousing } \\
\text { words }\end{array}$ & 0 & $\mathbf{0 \%}$ \\
\cline { 2 - 4 } & $\begin{array}{l}\text { Use visual images to evoke } \\
\text { emotions }\end{array}$ & 0 & $\mathbf{0 \%}$ \\
\cline { 2 - 4 } & $\begin{array}{l}\text { Use appropriate metaphors } \\
\text { and similes }\end{array}$ & 2 & $\mathbf{2 . 0 2 \%}$ \\
\cline { 2 - 4 } & Use appropriate fear appeals & 0 & $0 \%$ \\
\cline { 2 - 4 } & $\begin{array}{l}\text { Consider using appeals to } \\
\text { several emotions }\end{array}$ & 9 & $\mathbf{9 . 0 9 \%}$ \\
\hline & $\begin{array}{l}\text { Tap audience members' } \\
\text { beliefs in shared myths }\end{array}$ & 1 & $\mathbf{1 . 0 1 \%}$ \\
\hline Total & $\mathbf{2 6}$ & $\mathbf{1 0 0 \%}$ \\
\hline
\end{tabular}

The table above shows that in prospecting the customers who are in different-age (older) group, the insurance agents generally used both persuasive strategies. However, some methods such as causal reasoning, using emotion-arousing words, using visual images, and using appropriate fear 
appeals were not used. Maybe, the insurance agents would use causal reasoning if the customers had a lot of questions. However, most of the time, it was the insurance agents who took the dominant role because they were still in the step of presenting the concept or product. There was a possibility that causal reasoning would be used by the insurance agents if they were in the next step of prospecting. Meanwhile, the insurance agents did not use using emotion-arousing words and appropriate fear appeals at all maybe because the insurance agents just knew the customers slightly. Moreover, from the table we could see that the insurance agents used more logic and evidence in persuading the same-age customer, especially by using deductive reasoning $(45.45 \%)$. Probably, the insurance agents used deductive reasoning when they needed to explain and elaborate their ideas.

Then, the writer would answer the second research question regarding the differences and similarities of persuasive strategies used by insurance agents in prospecting customers. This following table would show the result:

Table 3: Occurrence of Persuasive Strategies Used by Insurance Agents in Prospecting Customers who are in the Same-age group and Different-age (Older) group

\begin{tabular}{|l|l|c|c|}
\hline \multicolumn{2}{|c|}{ Persuasive Strategies } & $\begin{array}{c}\text { Same-age } \\
\text { Group } \\
\text { Customers }\end{array}$ & $\begin{array}{c}\text { Different-age } \\
\text { (Older) Group } \\
\text { Customers }\end{array}$ \\
\hline $\begin{array}{l}\text { Using Logic and } \\
\text { Evidence to } \\
\text { Persuade }\end{array}$ & Inductive Reasoning & $\mathbf{3 3 . 3 3 \%}$ & $\mathbf{2 8 . 2 8 \%}$ \\
\cline { 2 - 4 } & Deductive Reasoning & $\mathbf{2 6 . 8 8 \%}$ & $\mathbf{4 5 . 4 5 \%}$ \\
\cline { 2 - 4 } & Causal Reasoning & $\mathbf{0 \%}$ & $\mathbf{0 \%}$ \\
\cline { 2 - 4 } & TOTAL & $\mathbf{6 0 . 2 1 \%}$ & $\mathbf{7 3 . 7 3 \%}$ \\
\hline $\begin{array}{l}\text { Using Emotion to } \\
\text { Persuade }\end{array}$ & $\begin{array}{l}\text { Use concrete examples that } \\
\text { help your listeners visualize } \\
\text { what you describe }\end{array}$ & $\mathbf{2 2 . 5 8 \%}$ & $\mathbf{1 4 . 1 4 \%}$ \\
\cline { 2 - 4 } & $\begin{array}{l}\text { Use emotion-arousing } \\
\text { words }\end{array}$ & $\mathbf{0 \%}$ & $\mathbf{0 \%}$ \\
\cline { 2 - 4 } & $\begin{array}{l}\text { Use visual images to evoke } \\
\text { emotions }\end{array}$ & $\mathbf{1 . 0 7 \%}$ & $\mathbf{0 \%}$ \\
\cline { 2 - 4 } & $\begin{array}{l}\text { Use appropriate metaphors } \\
\text { and similes }\end{array}$ & $\mathbf{3 . 2 2 \%}$ & $\mathbf{2 . 0 2 \%}$ \\
\cline { 2 - 4 } & Use appropriate fear appeals & $\mathbf{0 \%}$ & $\mathbf{0 \%}$ \\
\cline { 2 - 4 } & $\begin{array}{l}\text { Consider using appeals to } \\
\text { several emotions }\end{array}$ & $\mathbf{1 1 . 8 3 \%}$ & $\mathbf{9 . 0 9 \%}$ \\
\cline { 2 - 4 } & $\begin{array}{l}\text { Tap audience members } \\
\text { beliefs in shared myths }\end{array}$ & $\mathbf{1 . 0 7 \%}$ & $\mathbf{1 . 0 1 \%}$ \\
\cline { 2 - 4 } & TOTAL & $\mathbf{3 9 . 7 8 \%}$ & $\mathbf{2 6 . 2 6 \%}$ \\
\hline
\end{tabular}

From the table above we could see the differences between persuasive strategies used by $\mathrm{X}$ insurance agents in prospecting customers who are in the same-age group and customers who are in different-age (older) group. Firstly, the difference was the percentage of persuasive strategies used by the agents. Secondly, the difference could be seen in the percentage of insurance agent using emotion to persuade (39.78\% using emotion to persuade same-age customers and $26.26 \%$ using emotion to persuade different-age (older) customers). Moreover, insurance agents used inductive reasoning $(33.33 \%)$ more than deductive reasoning while prospecting customers who are in the same-age group. Contrarily, the insurance agents used more deductive reasoning $(45.45 \%)$ while prospecting older customers. This could possibly happen because older customers are considered to be more critical compare to the same-age customers. In the transcript, older customers sometimes asked for more detailed explanation about the product, process, or regulation whereas the younger ones were more concerned about the general ideas of the insurance. Deductive reasoning probably was the best method for the insurance agents to explain things because usually older people do not like to listen to something which is too complicated or confusing. They tend to focus more on the main point rather than the support because they may already know about many things and have a lot of experiences more than the insurance agents. 
We could also see the similarities between persuasive strategies used by $\mathrm{X}$ insurance agents in prospecting customers who are in the same-age group and customers who are in different-age (older) group from the table above. Firstly, the insurance agents used both persuasive strategies proposed by Beebe \& Beebe (2012) in prospecting both customers' groups; however, causal reasoning, emotion-arousing words, and appropriate fear appeals were not used at all. Another similar thing was the rank of persuasive strategies' methods used by insurance agents in prospecting both groups. The third rank went to "use concrete examples that help your listeners visualize what you describe", continued with "consider using appeals to several emotions" on the fourth rank, and "use appropriate metaphors and similes" was on the fifth rank. In addition to that, the least-used method used by insurance agents was "tap audience members' beliefs in shared myths". "Tap audience members' beliefs in shared myths" was only used by one insurance agent; therefore, probably this method was not a strategy used by insurance agents in general. People's belief or shared myths was different from one to another and it was related to the social background. It might be difficult for the agents to tap the customers' myth. Furthermore, belief or shared myth is a sensitive topic in Indonesia. The next similarity was that in prospecting both customers from same-age and older group, the insurance agents used "using logic and evidence to persuade" more rather than "using emotion to persuade".

This study found out that the customers' age factor did not really affect the way insurance agents prospect their customers. It revealed that the insurance agents use more logic and evidence to persuade both customers' groups. The writer assumed that this could possibly happen because of some factors. The first possible factor was the step of the prospecting process. There are some steps in prospecting customers to join insurance, such as getting the customers' data, presenting the concept or product, following up the customers, and so on. All the insurance agents' in this study were in the step of presenting the concept or presenting the product. The agents would often persuade the customers using description or narration in presenting a concept or product because they were required to use more examples and analogy. Therefore, they might use more inductive and deductive reasoning. Another possible factor was the customers' social background. The customers in this study were mostly worker, teacher, and businesspeople which implied that there was a high possibility that they had good educational background. As workers and businesspeople, they were likely to use their logic rather than emotion.

\section{CONCLUSION AND SUGGESTIONS}

This study concluded that the insurance agents used both persuasive strategies proposed by Beebe \& Beebe (2012) in prospecting both same-age and older customers. However, this study also revealed that there were differences between the persuasive strategies used by insurance agents in prospecting same-age group customers and older customers. One important different thing was that while prospecting customers who are in the same-age group, insurance agents used more inductive reasoning rather than deductive reasoning. On the other hand, the insurance agents used more deductive reasoning than inductive reasoning while prospecting older customers.

This study also found some similarities between persuasive strategies used by insurance agents in prospecting customers who are in the same-age group and customers who are in differentage (older) group. One important similarity was that in prospecting both customers from same-age and older group, the insurance agents used "using logic and evidence to persuade" more rather than "using emotion to persuade" as their persuasive strategy.

In conclusion, the writer found out that actually the customers' age factor did not really affect the way insurance agents prospect their customers. This study showed that the insurance agents use more logic and evidence to persuade both customers who are in the same-age group and customers who are in different-age (older) group.

Also, the writer hoped that the readers would conduct a further research related to this research. Those who are interested in analyzing the similar topic to this study could give another limitation to the customer's background; for example by choosing the customers based on their profession. Moreover, it would be much better if other researchers do an interview with the insurance agents regarding their thought and consideration while using persuasive strategies. 


\section{REFERENCES}

Alexander, M. (2012). Persuasive Strategies Used by James Farmer Jr. and Samantha Booke in the Great Debaters Film: (Thesis No. 02012009/ING/2012). Unpublished Undergraduate Thesis, Petra Christian University, Surabaya.

Beebe \& Beebe. (2012). Public Speaking: An Audience-Centered Approach (8th ed.). Boston: Pearson Education.

Hatane, M. (2011). The Persuasive Strategies Used on the Phone by Male and Female Insurance Salespeople in Surabaya: (Thesis No. 02011946/ING/2011). Unpublished Undergraduate Thesis, Petra Christian University, Surabaya.

Insurance agent. (n.d.) Farlex Financial Dictionary. (2009). Retrieved November 012016 from http://financial-dictionary.thefreedictionary.com/Insurance+agent

Kotler, P \& Armstrong, G. (2004). Principles of Marketing (10th ed.). New Jersey, USA: Pearson. Larson, C. U. (2004). Persuasion: Reception and Responsibility. Belmont: Thomson Learning Inc. Yoon et al. (2005). Cognition, Persuasion, and Decision Making in Older Consumer. Netherlands: Springer Science + Business Media, Inc. 